\title{
Plant food anti-nutritional factors and their reduction strategies: an overview
}

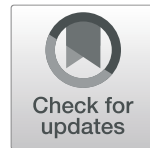

\author{
Mrinal Samtiya ${ }^{1}$, Rotimi E. Aluko ${ }^{2}$ and Tejpal Dhewa ${ }^{1 *}$ (D)
}

\begin{abstract}
Legumes and cereals contain high amounts of macronutrients and micronutrients but also anti-nutritional factors. Major anti-nutritional factors, which are found in edible crops include saponins, tannins, phytic acid, gossypol, lectins, protease inhibitors, amylase inhibitor, and goitrogens. Anti-nutritional factors combine with nutrients and act as the major concern because of reduced nutrient bioavailability. Various other factors like trypsin inhibitors and phytates, which are present mainly in legumes and cereals, reduce the digestibility of proteins and mineral absorption. Anti-nutrients are one of the key factors, which reduce the bioavailability of various components of the cereals and legumes. These factors can cause micronutrient malnutrition and mineral deficiencies. There are various traditional methods and technologies, which can be used to reduce the levels of these anti-nutrient factors. Several processing techniques and methods such as fermentation, germination, debranning, autoclaving, soaking etc. are used to reduce the anti-nutrient contents in foods. By using various methods alone or in combinations, it is possible to reduce the level of anti-nutrients in foods. This review is focused on different types of anti-nutrients, and possible processing methods that can be used to reduce the level of these factors in food products.
\end{abstract}

Keywords: Legumes, Cereals, Phytic acid, Micronutrients, Fermentation, Lactic acid bacteria, Anti-nutrients

\section{Introduction}

In Asian countries, cereals and legumes are considered as major staple foods. Cereal grains such as rice, wheat and maize belong to the grass family Graminae and hold valuable place within the staple food crops, because they are consumed throughout the world. Cereal grains provide ample amounts of carbohydrates, proteins, vitamins and most importantly dietary fibers, which are necessary for our daily diet as well as growth and maintenance of the human body (Nadeem et al. 2010). Wheat is one of the key edible food crops, which is consumed by almost onethird of the world's population. Wheat is the most diverse crop, which is grown throughout the world with approximately 750 million tons produced annually (FAOSTAT 2016). Wheat is mainly considered a high nutritive value cereal crop because of its composition, and contents of macronutrients like proteins, carbohydrates and fats, in addition to minerals such as zinc, phosphorus, iron, calcium, magnesium (FAO 2018a, b). Recently, wheat-

\footnotetext{
* Correspondence: tejpaldhewa@gmail.com

${ }^{1}$ Department of Nutrition Biology, Central University of Haryana,

Mahendergarh, Haryana 123031, India

Full list of author information is available at the end of the article
}

based foodstuffs have gained extensive attention in the consumer market and also from the food companies due to their health beneficial components. One example is the wheat flour-based cookies, which are made by baking into a product with very little moisture content and serve as source of energy for consumers (Adeyeye and Akingbala 2016; Okaka 1997). Maize or corn (Zea mays L.) is the key cereal crop, which is cultivated throughout the world and considered as a vital source of food for humans as well as feed for livestock (Tenaillon and Charcosset 2011; Gwirtz and Garcia-Casal 2014). After wheat and rice consumption levels, corn is considered as the $3^{\text {rd }}$ most important cereal crop worldwide (De Vasconcelos et al. 2013). Corn is consumed in various forms such as snacks, main dishes and children's foods; it is cultivated in large parts of the world mainly in Asia, Africa and America (Ekpa et al. 2018; Aoudou et al. 2012). Corn contains 65 to $84 \%$ starch, 9 to $10 \%$ protein, 3 to $5 \%$ fat, $3 \%$ ash and 2 to $3 \%$ fibre (Ihekoronye and Ngoddy 1985). Corn consists of ample amounts of essential minerals and the B vitamins; therefore, when consumed as whole grains, it could deliver sufficient quantity of nutrients (Ranum et al. 2014). Moreover, corn bran is a rich source of dietary 
fibre that can be applied to human foods, as well as in animal feed formulations (Rose et al. 2010). Corn possesses rich amounts of water and fat-soluble vitamins, which act as precursors for vitamin A (Oboh et al. 2010). In respect of nutritional quality, cereals contain low amounts of proteins but high amounts of carbohydrates. For example, wheat flour contains $10 \%$ protein content but nearly $87 \%$ of carbohydates, while Bajra or Pearl Millet (P. glaucum) contains $11 \mathrm{~g}$ of protein and approximately $73 \mathrm{~g}$ of carbohydrates (Kavitha and Parimalavalli 2014; Malik 2015). In terms of nutritional composition, cereals are rich sources of carbohydrates, vitamins and fibre but they are deficient (limiting) in the amino acid lysine. In contrast, legumes are rich sources of lysine; therefore, cereal flours can be supplemented with legumes to overcome the limiting amino acid problem (Katina et al. 2005; Awolu et al. 2015, 2017). Cereal grains are also considered as rich sources of minerals mainly zinc and iron, in addition to ample amounts of vitamins and calories (Temba et al. 2016). Many cereal bars also come into consideration because some snack bars made from cereals, may be formulated to contain lesser amounts of total calories (Suhem et al. 2015). Cereals, which come under coarse category are also known as 'nutricereals' due to their exceptional functional and nutritional properties. Coarse cereals commonly include corn, sorghum, oats, barley, pearl millet and finger millet (Kaur et al. 2014). During growth, plants synthesize various types of phytochemicals or secondary metabolites by using shikimate pathways (Zhang et al. 2015). Along with corn and wheat, rice (Oryza sativa L.) is one of the principal edible cereal crops, which is consumed for human nutrition. After sugarcane (1.9 billion tonnes) and corn (1.0 billion tonnes), rice is the third highest cultivated staple crop worldwide at 741.5 million tonnes (Kennedy and Burlingame 2003; FAOSTAT 2017). In the Asian regular diet, cooked rice is mainly consumed as a whole grain and it adds about 40$80 \%$ to the over-all calorie intake (Paramita et al. 2002; Hossain et al. 2009; Singh et al. 2005). In terms of various advantages, rice starch is much better than corn with respect to flavor (bland), colour (white), greater resistance to acid and hypo-allergenic properties (Wani et al. 2012). Pearl millet is considered an edible crop, which shows resistance against drought conditions and also cultivated mainly in sub-saharan Africa and India as an essential food, though India is the main producing country (Wang et al. 2018).

In traditional systems, indigenous knowledge plays a key role in disease diagnosis and health care practices, which has encouraged consumption of cereals throughout the world as a main source of nutrients in various diets. In addition, recent trends indicate an increased demand for conventional or major tropical cereals. However, millets have been neglected and are underutilized even though they have tremendous potential as an economic and food crop. Food quality assessment of this type of underutilized crop can lead to increased sustainability or food security while improving the economic condition and human health of rural populations (Gopalan et al. 1989; Ebert 2014). This is because millets can be consumed as flour, breakfast food with milk, rolled into balls or parboiled and are recognized as high energy-containing foods, which can help in combating malnutrition (FAO 2018a, b, 2009). Consumption of whole cereal grains could protect against obesity, cardiovascular diseases, diabetes and other types of chronic health disorders (Oghbaei and Prakash 2016). For example, millets have antioxidative properties due to the presence of phenolic compounds, which have been shown to protect against cardiovascular diseases (Kumari et al. 2019).

Legumes are edible crops that belong to the Leguminosae family and second only to cereals in terms of level of human consumption (Sánchez-Chino et al. 2015; Seigler 2005). Common legumes, which are consumed all over the world include cranberry beans, black beans, Great Northern beans, navy beans, chickpeas, kidney beans, lentils etc. Legume grains contain desirable levels of ingredients that can enhance nutritional quality such as high protein concentration, potassium, fiber, and low glycemic index. Consumption of legume seeds is believed to have a strong impact on blood pressure reduction while conferring antioxidant benefits (Polak et al. 2015; Vaz Patto et al. 2015). Soybean (Glycine max) comes under the leguminous family; it is widely grown in tropical, subtropical and temperate climates, containing a higher amount of protein $(36 \%)$ than cereals, nearly $30 \%$ of carbohydrates and exceptional amounts of minerals, vitamins and dietary fiber. Soybean is one of the most important crops used for producing edible oil because the seed contains about $20 \%$ of oil (Edema et al. 2005; Food and Agricultural Organization of the United Nations 2004; Gibson and Benson 2005). Soybean could also be used for making nutritious food products such as cookies, snack foods, bread, soups and pasta due to the rich protein concentration as well as balanced amino acid profile (Edema et al. 2005). Silva et al. (2019) reported that soybean is also used for producing soymilk, which can be consumed as such or used for preparing fermented soymilk, tofu and soy yogurt.

It has been found that significant amounts of sulphurcontaining amino acids like methionine and cysteine are present in cereal grains. Methionine and cysteine have many nutraceutical properties that are helpful to prevent health disorders such as lowering the risk of cardiovascular diseases, reduced blood pressure, and decreased incidence of tumor. Leguminous crops mainly provide ample amounts of protein when compared to cereals. In comparison to meat, eggs and poultry, soybean is the only crop, which provides a cheap and high quality 
protein (Edema et al. 2005; Food and Agricultural Organization of the United Nations 2004). In developing countries, one of the key nutritional problems is protein energy malnutrition (Edema et al. 2005). Soybean has much supreme concentration of protein, fibre, minerals and vitamins; the high concentration of fibre in soybeans may help in reducing the incidence of type- 2 diabetes, constipation and hypercholesterolemia (Gibson and Benson 2005; Edema et al. 2005; Food and Agricultural Organization of the United Nations 2004). Peanut or groundnut (Arachis hypogaea L.) also comes under the leguminous family; it is a seed crop, which is cultivated in tropical and subtropical climates. It consumed in different forms including as a component of formulated or processed foods, roasted nut and also for edible oil extraction (Stalker 1997). Groundnut seeds are good sources of several essential minerals such as calcium, phosphorus, magnesium and zinc as well as vitamin B1 (FAO 2002). Groundnut also contains ample amounts of vitamin $\mathrm{E}(\alpha-$ tocopherol), which is widely used to prevent oxidative deterioration in lipid-rich foods (de Camargo and Silva et al. (2019). Kersting's groundnut (Kerstigiella geocarpa Harms) is considered an underutilized legume; it consists of high amounts of essential minerals, protein and amino acids. The crop is grown mainly in Africa and is considered an alternative to high protein foods (Bayorbor et al. 2010).

In rural areas, micronutrient deficiencies such as those involving vitamins and minerals are one of the biggest causes of health-related problems (Black et al. 2013). This is because the presence of micronutrients in bulk amounts is not the only important nutritional factor but also their bioavailability is critical in meeting human nutrient needs. In raw foodstuffs, the lower mineral bioavailability decreases the nutritional value of these foods, which could lead to the development of metabolic health disorders. Thus, the nutritional condition of a population can be improved by enhancing bioavailability of food nutrients (Bouis et al. 2019; Gupta et al. 2015). Unfortunately, millets, though cheap and can be grown easily are reported to have low a nutritional value due to the presence of anti-nutritional factors, which reduce nutrient bioavailability (Sarita and Singh 2016). Legumes also comprise of many natural toxicants or anti-nutrients, which include tannins, metal chelators, protease inhibitors, saponins, cyanogens, phytic acid, isoflavonoids, etc. (Pariza 1996). One of the major anti-nutrients is phytate, which chelates and mainly affects bioavailability of calcium and other micronutrients such as iron, copper and zinc. Some other factors such as polyphenols and oxalates are also considered as anti-nutrients that can limit food mineral bioavailability (Kaushik et al. 2018). However, phytochemicals such as phenolic compounds show antioxidant activity through their potency in scavenging ROS, reducing power and/or metal-chelating activity towards ferric and ferrous ions. While not all polyphenols exhibit chelating properties, phytochemicals like isoflavones, genistein and biochanin A are considered as ideal antioxidants because they possess the quality of reducing agents in addition to metal ionchelating properties (de Camargo et al. 2019).

Like other grains, several anti-nutritional factors are found in wheat, which may have effect on the digestibility of wheat products and by this means, affect human health (FAO 2018a, b). Anti-nutrients can have significant adverse effects on the nutritional value of foods; therefore, reducing their concentration in foods is a major goal in human nutrition. Subsequently, legumes are commonly eaten as protein sources along with cereals, but in order to eliminate the anti-nutrients, suitable processing of these food substances should be encouraged before their consumption (Reddy and Pierson 1994). Like other legumes, peanuts are also comprised of anti-nutrients, which can impair nutrient bioavailability through formation of indigestible complexes with minerals and proteins (Francis et al. 2002; Lönnerdal 2002). In addition to decreasing nutrient bioavailability, anti-nutrients can become toxic when present beyond a certain amount. Therefore, reduction in the levels of anti-nutritional factors in edible crops is an area of research interest due to the need to prevent toxicity and associated health problems caused by these anti-nutrients (Gemede and Ratta 2014).

The anti-nutritional factors, which reduce the nutritional value of foods can be reduced by the use of traditional food preparation methods such as fermentation, cooking, soaking and puffing. These food processing techniques reduce anti-nutritional factors, increase protein digestibility and improve the biological value of cereal crops (Handa et al. 2017; Jaybhaye and Srivastav 2015). Therefore, the main focus of this review is to discuss various anti-nutrients present in foods and also assess processing methods that can be used to reduce the concentration of anti-nutritional factors such as phytate, saponins, polyphenols and protease inhibitors.

\section{Anti-nutrient factors}

Several types of anti-nutritional factors with toxic potential have been measured in foods and shown to be heatstable or heat-labile. These factors include saponins, tannins, phytic acid, gossypol, lectins, protease inhibitors, amylase inhibitors, antivitamin factors, metal binding ingredients, goitrogens, etc. Nutrition-related problems and harmful effects to human health are raised by these factors, which are present in the seeds of cereals and legumes. Figure 1 shows a brief overview of the adverse effects of key anti-nutrients that are present in foods.

\section{Saponins}

Saponins are commonly considered as non-volatile, surface active secondary metabolites, which are broadly 


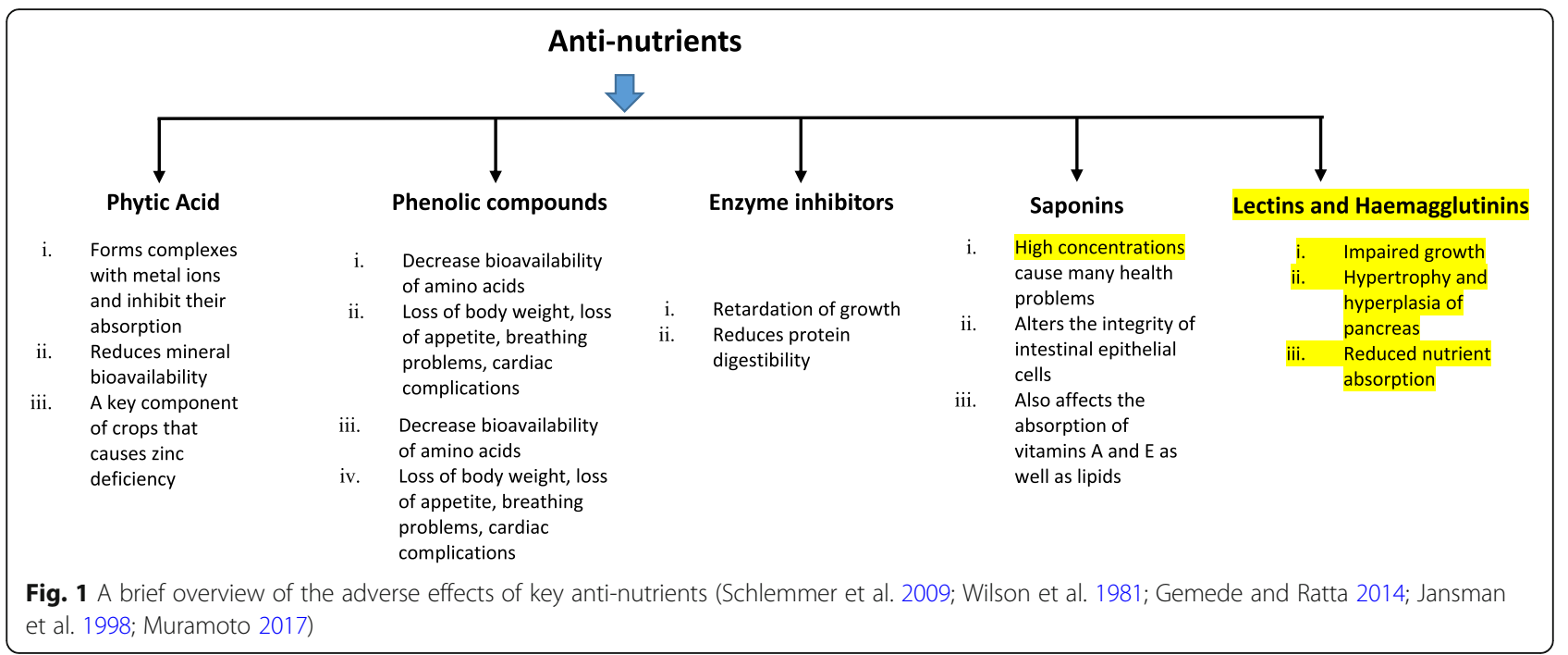

dispersed in nature but found principally in plants. Saponins are steroids or triterpenes and contain a sugar moiety in their structure. They are naturally produced as foam-producing triterpene or glycosides by many plant species, including groundnut, lupin, oil seeds, etc. (Kiranmayi 2014). Triterpenoid saponins are usually found in most cultivated crops such as legumes (e.g. soybean, peanuts, chickpeas, broad beans, and lentils), sunflower seeds, spinach leaves, tea leaves, quinoa seeds, sugar beet and allium species. In contrast, steroid saponins are generally present in food plants such as oats, yucca, tomato seeds, fenugreek seeds, asparagus, aubergine, and yam (Fenwick et al. 1991; Moses et al. 2014). Saponins are plant-derived secondary compounds, which are found in more than 100 families of wild and cultivated plants that belong to the Magnoliophyta division. Magnoliophyta can be divided into two key classes: Liliopsida and Magnoliopsida, which contain majority of species that produce saponins (Vincken et al. 2007). Saponins have a property of being able to interact with the cholesterol group of erythrocyte membranes, which leads to hemolysis (Fleck et al. 2019). Previous studies have reported that saponins also showed inhibitory activities of digestive enzymes such as amylase, glucosidase, trypsin, chymotrypsin and lipase, which can cause indigestion-related health disorders (Ali et al. 2006; Birari and Bhutani 2007; Ercan and El 2016; Lee et al. 2015; Liener 2003). Glucosidases are carbohydrate-hydrolyzing enzymes, which are mainly involved in the breakdown of glycosidic bonds in complex sugars. $\alpha$-Glucosidase is one of the important glucosidases, which is present in the brush border of the small intestine. $\alpha$-Glucosidase facilitates glucose absorption by breaking the glycosidic bonds in disaccharides and starch to produce the simpler and more absorbable monosaccharides (Kumar et al. 2011). Saponins are not readily hydrolyzed by the human digestive enzymes, therefore gastrointestinal digestion can be severely impaired (Amin et al. 2011). Previous studies have demonstrated that animal metabolism and health could be affected by saponins in different ways. The effects include bloating in ruminants, reduced nutrient absorption, decreased liver cholesterol and overall growth rate, and reduced intestinal absorption of many nutrients through binding of saponins to the small intestine cells (Addisu and Assefa 2016; Kregiel et al. 2017). It should be noted that the low levels of saponins in legumes may not be injurious to health but could become toxic when consumed at higher concentrations in the diet (Jansman et al. 1998). For example, sheep were died when fed saponin levels $\geq 150 \mathrm{mg} / \mathrm{kg}$ body weight (Williams 1978). Saponins are also considered as factors that reduce absorption of vitamins. It has been suggested that saponins can form complexes with various sterols that have similar structures as fat-soluble vitamins, which would interfere with sterol activity and absorption (Cheeke 1971). A previous study by Jenkins and Atwal (1994) reported that a diet prepared by using Gypsophila and Quillaja, which contained triterpenoid saponins, reduced the absorption of vitamins $\mathrm{A}$ and $\mathrm{E}$ when fed to chicks.

\section{Phytates}

Phytates or phytic acids occur naturally in the plant kingdom. Phytate is generally known as myo-inositol-1,2, 3,4,5,6-hexakis dihydrogen phosphate, which is present in foods at various levels ranging from 0.1 to $6.0 \%$ (Gupta et al. 2015). Phytic acid is a secondary compound, which concentrates naturally in plant seeds, mainly in legumes, peanuts, cereals, and oilseeds and generally found in all plant-based foods (Lolas 1976; García-Estepa et al. 1999). In several cases, phytates contain about 50 to $80 \%$ of the total phosphorous in seeds 
(Lott et al. 2000; Raboy 2000). Because plant-based foods contain more amount of phytic acids than animal-based foods, the vegetarian diets culture in developing countries contribute to high ingestion levels (Kwun and Kwon 2000; Amirabdollahian and Ash 2010). According to a previous report, phytic acid hinders the activity of enzymes, which are necessary for protein degradation in the small intestine and stomach (Kies et al. 2006). Generally, phytic acids affect the bioavailability of minerals and has a strong effect on infants, pregnant and lactating women when large portions of cereal-based foods are consumed (Chan et al. 2007; Al Hasan et al. 2016). During germination of seeds, some native enzymes are activated, which degrade the phytic acid (Kaukovirta-Norja et al. 2004; Larsson and Sandberg 1992). In wheat and rice, which are generally recognized as monocotyledon crops, phytates are present in the bran or aleurone layer and can be easily separated during milling. On the other hand, in diacotyledons such as legumes, oilseeds and nuts, phytates are found in close association with proteins, which reduces ease of separation by a simple processing method like milling (Sinha and Khare 2017). Phytic acid is generally a negatively-charged structure, which generally binds with positively-charged metal ions such as zinc, iron, magnesium and calcium to make complexes and reduce the bioavailability of these ions through lower absorption rates. Mainly due to this chelating property, phytic acid is considered as a most effective anti-nutrient in foods, and a cause of mineral ions deficiencies in animal and human nutrition (Grases et al. 2017; Bora 2014).

\section{Tannins}

Tannins are phenolic compounds, which consist of molecular weights greater than $500 \mathrm{Da}$. One of the properties of these compounds is that they can precipitate proteins. Tannins are secondary compounds, which are formed in plant leaves, fruits and bark (Timotheo and Lauer 2018). Tannins usually affect protein digestibility and lead to reduction of essential amino acids by forming reversible and irreversible tannin-protein complexes between the hydroxyl group of tannins and the carbonyl group of proteins (Lampart-Szczapa et al. 2003; Raes et al. 2014). Proteins, which generally form complexes with tannins are relatively large and hydrophobic in nature, in addition to an open and flexible structure that is enriched with proline (Frutos et al. 2004). Tannins are largely concentrated in beverages, pomegranate, berry fruits and cocoa bean, although they are also found in cereals such as sorghum and barley (Serrano et al. 2009; Morzelle et al. 2019). In nature, there are two types of tannin groups: hydrolyzable (e.g. gallotannins and ellagitannins) and condensed (e.g. proanthocyanidins). Peanut and millets also contain proanthocyanidins (condensed tannins) in ample amounts (de Camargo and da Silva Lima 2019; Chandrasekara and Shahidi 2011). In ruminants, hydrolysable type of tannins are readily broken down during the digestion process. The breakdown products constitute a large amount of compounds, which can be toxic (Kumar 1992). Leguminous forage and some seeds generally contain mostly condensed tannins. Previous studies showed that goats are resistant to these tannins while cattle and sheep are sensitive (Smeriglio et al. 2017; Bhattarai et al. 2016; D'Mello 2000). Tannins accumulate mainly in the bran section of the legumes. When ingested, tannins form complexes with proteins, which cause inactivation of many digestive enzymes and decrease protein digestibility (Joye 2019).

\section{Enzyme inhibitors}

Proteinases are enzymes, which have diverse roles in improving nutritional and functional properties of various protein molecules (Salas et al. 2018). Various proteolytic actions are performed by proteases inhibitors (PIs) such as signal initiation, transmission and cellular apoptosis, inflammatory response, blood coagulation and several pathways of hormone processing (Gomes et al. 2011). Cereal seeds mainly contain plant serpins, one of the largest protease inhibitor family, which are also known as "suicide inhibitors" having molecular weight of 39 to 43 $\mathrm{kDa}$ and also found in several other species in the plant kingdom (Habib and Fazili 2007; Haq et al. 2005). Serpins are the effective inhibitors, which generally inhibit trypsin and chymotrypsin activities by acting upon the overlapping reactive sites of the enzymes (Dahl et al. 1996). Protease inhibitors are natural plant inhibitors, which have become an important research area due to their effective way of limiting enzyme activity by forming protein-protein interactions. They inhibit the enzyme activity through the catalytic mode by blocking the active site of the enzymes. The $\mathrm{N}$ - or $\mathrm{C}$-terminus and the exposed loop of protease inhibitors are frequently considered important structural features for the inhibition of enzyme activity (Otlewski et al. 2005). Ragi contains bifunctional inhibitor, which inactivates the protein and starch-degrading enzymes by making trimetric complex interactions with trypsin and $\alpha$-amylase, respectively (Shivaraj and Pattabiraman 1981). Legumes contain high amounts of protease inhibitors, $\alpha$-amylase inhibitors and lectins, which could lead to low minerals bioavailability as well as reduced nutrients absorption and digestibility (Bajpai et al. 2005; Yasmin et al. 2008). Compared to legumes, cereals contains much lower amounts of these digestion inhibitors, especially those that act against proteases and amylases (Nikmaram et al. 2017). Within the gastrointestinal (GI) tract of animals, proteolytic enzyme activity could be severely inhibited by protease inhibitors present in diets (Nørgaard et al. 2019). The Kunitz 
trypsin inhibitor and Bowman-Birk inhibitor are two kinds of protease inhibitors, which are commonly found in soybean but are not readily inactivated by heat treatment due to the presence of disulfide bridges (Liu 1997; Van Der Ven et al. 2005). There are several enzyme inhibitors that are present in plant-derived foods but those that affect trypsin and $\alpha$-amylase activities are the two key types, which are found in almost all cereals and legume-based foods. $\alpha$-amylase mainly regulates the breakdown of carbohydrates such as polysaccharides into oligosaccharides. Therefore, enzyme inhibitors that specifically inhibit $\alpha$-amylase activity will increase carbohydrate absorption time by delaying carbohydrate digestion. Due to the increased carbohydrate digestion time, glucose absorption rate is decreased and this affects the normal postprandial plasma glucose level (Bhutkar and Bhise 2012). Various previous studies have shown that seeds, which are rich in trypsin inhibitors may increase the satietogenic hormone i.e. cholecystokinin (CCK) and cause reduction in food intake and body weight (Serquiz et al. 2016; Chen et al. 2012; Ribeiro et al. 2015). Occurrence of trypsin inhibitors in human diets can lead to decreased growth rate by reducing protein digestion and availability of amino acids in addition to causing pancreatic hyperplasia (Adeyemo and Onilude 2013). However, several studies have reported that enzyme inhibition (e.g. alpha-amylase, alpha-glucosidase, lipase) may also provide health benefits related to the prevention of type 2 diabetes and obesity as discussed by Li and Tsao (2019).

\section{Lectins and haemagglutinins}

Lectins and hemagglutinins are a form of sugar-binding proteins, which easily attach to red blood cells to cause agglutination. These anti-nutrients are mainly found in foods, which are consumed in raw forms (Hamid et al. 2013). Cereals and legumes generally contain lectins, which are glycoproteins. In addition, transport and hydrolytic functions of the enterocyte would be impaired by consumption of foods that contain lectins (Krupa 2008). Phytohemagglutinin is a tetrameric glycoprotein with a molecular mass of $120 \mathrm{kDa}$, which is found in kidney beans and also consists of two diverse subunits (Lajolo and Genovese 2002). In rats, kidney bean phytohemagglutinin appears to upregulate the function and metabolism of the whole gastrointestinal tract, which includes growth of the small intestine, increased length of the tissue and number of intestinal crypt cells (Bardocz et al. 1995). In another study, phytohemagglutinins enhanced growth of the rat pancreas by increasing CCK hormone release; however, an independent mechanism was responsible for intestinal growth (Herzig et al. 1997). Purified lectins from beans or soybeans impaired rat growth, induced enlargement of the small intestine, caused damage to the epithelium of the small intestine, and stimulated hypertrophy and hyperplasia of the pancreas. Lectins impair nutrient absorption by binding to intestinal epithelial cells, and also cause damages in the intestinal tract, which allow bacterial population to come into contact with the blood stream (Muramoto 2017).

\section{Strategies used to reduce food levels of anti- nutrients}

Previous studies have shown that anti-nutrients cause adverse effects on diet value by reducing nutritional significance of foods. Prasad et al. (1963) reported that Egyptian boys were found deficient with zinc minerals, especially those that consumed bread and beans consistently. It is now very well accepted that phytate present in foods is one of the key concerns for the zinc deficiency. Jenkins and Atwal (1994) reported that dietary saponins reduced the growth and feed proficiency in chicks, while the absorption of vitamins $\mathrm{A}$ and $\mathrm{E}$ as well as lipids was also negatively impacted. A previous study by Lee et al. (1993) concluded that the metabolism of calcium, zinc and phosphorous was adversely affected when phytate was given to female rats. Besides their property of reduction of various minerals and nutrients, these anti-nutrients could cause toxicity when present in higher amounts in the diet. Due to these reasons, reduction in the anti-nutritional content of foods is of great interest. Different traditional methods and technological processing ways such as soaking, milling, debranning, roasting, cooking, germination and fermentation have been used for reducing these anti-nutritional components in foods. Here we describe various processing methods, which are used to decrease the concentration of phytate, tannin, saponins, etc. in foods (Table 1).

\section{Milling}

Milling is the most traditional method to separate the bran layer from the grains. It is a process by which grains are ground into flour. The milling technique removes anti-nutrients (e.g. phytic acid, lectins, tannins), which are present in the bran of grains, but this technique has a main disadvantage that it also removes important minerals (Gupta et al. 2015). For example, research on millet milling reported that the chemical composition of pearl millets was changed due to milling process. On the other hand, no much change was observed in pearl millet flour when processed through baking. However, milling and heating process during making of chapatti reduced the phytic acid and polyphenol contents in addition to significant improvements in starch and protein digestion (Chowdhury and Punia 1997). In another research, two varieties of pearl millets were used for evaluating their nutrients, anti-nutrients, and mineral bioavailability after milling them into whole flour, bran rich segment and semi-refined flour. The results of nutrient composition 
Table 1 Anti-nutrients and their concentrations in different food sources

\begin{tabular}{|c|c|c|c|}
\hline Source & Anti-nutrients & Concentration & References \\
\hline Mung bean & Total Phenol & 238 mg/100 g (d.w.) & Shi et al. 2016; Zujko et al. 2016 \\
\hline Chickpea & & 660 mg/100 g (d.w.) & \\
\hline \multirow[t]{4}{*}{ Soybean } & Tannin & $1.93 \mathrm{mg} / \mathrm{g}$ & Adeyemo and Onilude 2013 \\
\hline & Phytate & $1.16 \mathrm{mg} / \mathrm{g}$ & \\
\hline & Trypsin Inhibitor & $1.20 \mathrm{mg} / \mathrm{g}$ & \\
\hline & Protease Inhibitor & $1.20 \mathrm{mg} / \mathrm{g}$ & \\
\hline \multirow[t]{3}{*}{ Peanut seeds } & Phytic acid & $2.63 \mathrm{mg} / \mathrm{g}$ & Embaby 2010 \\
\hline & Tannins & $8.9 \mathrm{mg} / \mathrm{g}$ & \\
\hline & Trypsin Inhibitor activity & $5.6 \mathrm{mg} / \mathrm{g}$ & \\
\hline \multirow[t]{2}{*}{ Maize } & Phytate & $87.16-683.20 \mathrm{mg} / 100 \mathrm{~g}$ & Sokrab et al. 2011 \\
\hline & Polyphenol & $363.71-706.15 \mathrm{mg} / 100 \mathrm{~g}$ & \\
\hline \multirow[t]{2}{*}{ Wheat } & Tannin & $1.43-1.84 \mathrm{mg} / \mathrm{g}$ (d.w.) & Singh et al. 2012 \\
\hline & Phytic acid & $7.95-8.00 \mathrm{mg} / \mathrm{g}$ (d.w.) & \\
\hline \multirow[t]{2}{*}{ Rice } & Polyphenol & $172.11 \mathrm{mg} / 100 \mathrm{~g}$ & Kaushal et al. 2012 \\
\hline & Phytic acid & $93.70 \mathrm{mg} / 100 \mathrm{~g}$ & \\
\hline Pearl Millet & Tannin & $0.459 \mathrm{mg} / 100 \mathrm{~g}$ & Singh et al. 2017 \\
\hline Finger Millet & & $0.301 \mathrm{mg} / 100 \mathrm{~g}$ & \\
\hline Sorghum & & $0.601 \mathrm{mg} / 100 \mathrm{~g}$ & \\
\hline Pearl Millet & Phytic acid & $5.00 \mathrm{mg} / 100 \mathrm{~g}$ & \\
\hline Finger Millet & & $8.6 \mathrm{mg} / 100 \mathrm{~g}$ & \\
\hline Sorghum & & $3.4 \mathrm{mg} / 100 \mathrm{~g}$ & \\
\hline Kidney beans & Phytic acid & $627.33 \mathrm{mg} / 100 \mathrm{~g}$ & Margier et al. 2018 \\
\hline Chickpeas & & $693.94 \mathrm{mg} / 100 \mathrm{~g}$ & \\
\hline Kidney beans & Saponins & $106.02 \mathrm{mg} / 100 \mathrm{~g}$ & \\
\hline Chickpeas & & $121.86 \mathrm{mg} / 100 \mathrm{~g}$ & \\
\hline Peanut & Lectin & $0.14 \mathrm{mg} / \mathrm{g}$ & Ahmed 1986 \\
\hline Soybean & & $0.11 \mathrm{mg} / \mathrm{g}$ & \\
\hline
\end{tabular}

d.w. Dry weight

showed that no difference was found in semi-refined flour and whole flour except fat content, which was $1.3 \%$. However, the contents of phytate and oxalate were found to be low in semi-refined flour when compared with whole flour, due to removal of the bran fraction (Suma and Urooj 2014).

\section{Soaking}

Soaking is an attractive method for removing antinutrient content of foods because it also reduces cooking time. Soaking also enhances release of enzymes (e.g. endogenous phytases), which are present in plant foods like almonds and other nuts and grains. Soaking generally provides essential moist conditions in nuts, grains and other edible seeds, which are required for their germination and associated reductions in level of enzyme inhibitors as well as other anti-nutrients to enhance digestibility and nutritional value (Kumari 2018). Soaking is also commonly required for fermentation, which can also be used to reduce the level of various anti-nutrients in foods (Gupta et al. 2015). Many of the anti-nutrients are water soluble in nature, which enhance their removal from foods through leaching. Soaking generally increases the hydration level of legumes and cereals, which make them soft and also activate an endogenous enzyme like phytase to enhance ease of further processing such as cooking or heating. A previous study stated that $6 \mathrm{~h}$ soaking reduced $27.9 \%$ and $24 \mathrm{~h}$ of soaking reduced $36.0 \%$ of phytic acid at room temperature in Mucana flagellipes (Udensi et al. 2008). Due to soaking, activity of phytase increased, which reduced the phytate component present in the grains. As a result of soaking and fermentation, phytochemicals are reduced due to leaching of water-soluble vitamins and minerals in grains and legumes (Ogbonna et al. 2012; Kruger et al. 2014). However, soaking commonly reduces the content of anti-nutrient phytochemicals like phytate, 
tannins, etc. Therefore, due to these benefits, it was recommended that wheat and barley should be consumed after soaking for a period of time (Gupta et al. 2015), especially 12 to $24 \mathrm{~h}$ (Ertas and Turker 2014); Mahgoub and Elhag 1998; Onwuka 2006). For example, during soaking, endogenous or exogenous phytase enzymes could enhance the in vitro solubility of minerals such as zinc and iron by 2 to 23\% (Vashishth et al. 2017). A previous research carried out by Greiner and Konietzny (2006) showed that soaking reduced phytate content significantly at $45^{\circ} \mathrm{C}$ and $65^{\circ} \mathrm{C}$. Soaking of grains and beans was found much effective to enhance the minerals concentration and protein availability, accompanied by reductions in phytic acid level (Coulibaly et al. 2011). Another study reported that phytic acid concentration in chickpea was deceased by 47.45 to $55.71 \%$ when the soaking time was increased from 2 to $12 \mathrm{~h}$ (Ertaş and Türker 2014).

\section{Autoclave and cooking}

Autoclave is an application, which is generally used for heat treatments. When this application is used on cereals and other plant-based foods, it activates the phytase enzyme as well as increases acidity (Ertop and Bektaş 2018). Most of the foods showed health benefits when consumed after autoclaving. For example, boiling of food grains reduced anti-nutrients content, which improved their nutritional value (Rehman and Shah 2005). Soaking and cooking also greatly decreased the phytic content in legume grains (Vadivel and Biesalski 2012). Food legumes are generally cooked by boiling or by using a pressure cooker prior to consumption. Previous studies also reported that boiling or cooking highly improved the nutritional value of foods by reducing their antinutritional (e.g. tannins and trypsin inhibitors) contents (Patterson et al. 2017). Another study by Vadivel and Biesalski (2012) reported that phytic acid concentration drastically decreased in legume grains when they were treated with cooking and soaking. A previous study by Vidal-Valverde et al. (1994) showed much reduced amounts of phytic acid in lentils when the seeds were treated with soaking followed by cooking application for a short period. Another research by Mustafa and Adem (2014) reported that whole wheat bread, which was treated through autoclave and microwave application showed reduced level of phytic acid, but the level of total free (unbound) mineral content was increased. This is because phytic acid possess mineral-chelating property; therefore, reduction in phytates lowers the level of bound minerals while enhancing free mineral contents. Another study also reported that the nutritional quality of legumes was much improved after cooking due to reductions in the contents of lectins and saponins (Maphosa and Jideani 2017). In another study, it was reported that anti-nutrients of black grams and mung beans were reduced by pressure-cooking when compared to normal cooking treatment (Kataria et al. 1989). A study by Shah (2001) observed that pressure-cooking reduced the tannins content, which led to improved black gram protein digestibility. Savage and Mårtensson (2010) also reported that oxalate content of taro leaves was reduced by $47 \%$ when boiled in water for $40 \mathrm{~min}$, even though there was no significant reduction observed in oxalate content after baking for $40 \mathrm{~min}$ at $180^{\circ} \mathrm{C}$. Roasting method also decreased the trypsin inhibitor activity significantly in soybean meal (Vagadia et al. 2017). Another study observed that several anti-nutritional factors were reduced significantly after autoclaving, soaking and cooking of legumes (Torres et al. 2016). Most of the previous studies concluded that autoclaving is the best method to reduce levels of several anti-nutritional compounds when compared to other processing methods (Shimelis and Rakshit 2007; Vadivel et al. 2008; Doss et al. 2011).

\section{Germination}

Germination is also considered as a highly suitable method for reducing the anti-nutrient components of plant-based foods (Nkhata et al. 2018). Germination of seeds generally activates the enzyme phytase, which degrades phytate and leads to decreased phytic acid concentration in the samples. Germination commonly changes the nutritional level, biochemical property and physical features of the foods. For reduction of cereals anti-nutritional content, this method is most frequently used (Laxmi et al. 2015; Oghbaei and Prakash 2016; Onyango et al. 2013). Germinated cereals showed enhanced activity of phytase-degrading enzyme while in non-germinated cereals the endogenous activity of phytase enzyme was observed in diminished amounts (Vashishth et al. 2017). After malting of millet samples for $72 \mathrm{~h}$ and $96 \mathrm{~h}$, it was found that phytic acid content was reduced 23.95 and $45.3 \%$, respectively (Makokha et al. 2002; Coulibaly et al. 2011). In a previous work by Azeke et al. (2011), it was observed that phytate content of cereal grains samples was reduced significantly when estimated after 10 days of germination. Another study conducted by Zhang et al. (2015) reported that antinutrient factors including total phenolic, flavonoid and tannin contents were increased in germinated buckwheat samples. Latest studies reported that germination also changes the isoflavone profile of soybean due to activation of $\beta$-glucosidases; this is important in enhancing nutritional value because isoflavones exhibit chelating properties (Yoshiara et al. 2018; de Camargo et al. 2019). Reduction of anti-nutrients like tannin and phytic acid in germinated cereals increase the bioavailability of several minerals, which led to increased nutritional value of the food products (Ogbonna et al. 2012; Oghbaei and Prakash 2016). Another latest study by Singh et al. 
(2017) reported that when millets were processed by germination, maximum reductions in polyphenol contents (up to $75 \%$ ) were found when compared to soaking, microwave treatment and fermentation.

\section{Fermentation}

Fermentation may be a useful strategy for reducing bacterial contamination of foods. For treating diarrhea in young children, fermented millet products are recommended as probiotics (Manisseri and Gudipati 2012; Nduti et al. 2016). Fermentation is a metabolic process in which sugars are oxidized to produce energy; it also improves the absorption of minerals from the plantbased foods. Fermentation is one of the processing methods, which is used in Africa to made cereals crops edible and also increase the nutritional quality as well as safety aspects of these foods, because cereals are not easily consumed in natural/raw forms (Galati et al. 2014). In cereals, phytic acid normally forms complexes with the metal cations including iron, zinc, calcium and proteins. These complexes are generally degraded by enzymes, which require an optimum $\mathrm{pH}$ maintained by fermentation. Thus, this kind of degradation decreases the phytic acid content and liberates soluble iron, zinc and calcium, which enhance the nutritional level of food grains (Gibson et al. 2010). Fermentation of cereals by lactic acid bacteria (LAB) has been reported to increase free amino acids and their derivatives by proteolysis and by metabolic synthesis. Fermentation has been shown to improve the nutritional value of grains by increasing the content of essential amino acids such as lysine, methionine and tryptophan (Mohapatra et al. 2019).

Previous reports observed that several anti-nutrients including protease inhibitors, phytic acids and tannins were reduced due to millet grain fermentation for 12 and $24 \mathrm{~h}$ (Coulibaly et al. 2011). Fermentation is such an important process, which significantly lowers the content of anti-nutrients such as phytic acid, tannins, and polyphenols of cereals (Simwaka et al. 2017). Fermentation also provides optimum $\mathrm{pH}$ conditions for enzymatic degradation of phytate, which is present in cereals in the form of complexes with polyvalent cations such as iron, zinc, calcium, magnesium and proteins. Such a reduction in phytate may increase the amount of soluble iron, zinc, calcium several folds (Gupta et al. 2015). Tannin levels may be reduced as a result of lactic acid fermentation, leading to increased absorption of iron, except in some high tannin cereals, where little or no improvement in iron availability has been reported (Ray and Didier 2014). Reduction in polyphenols may be because of the presence of phenolic oxidase during germination (Tian et al. 2019; Tajoddin et al. 2014). In most of the cereals, Lactobacillus spp. plays a major role in fermentation (Bhatia 2016). Lactobacillus spp. and Streptococcus spp. are not very suitable bacteria for rice fermentation because they lack amylase, which is necessary for starch saccharification (Ray et al. 2016). In cases when cereal grains are used as natural medium for lactic acid fermentation, amylase needs to be added before or during fermentation or amylolytic bifido bacteria need to be used because these bacteria contain enough amylase, which is necessary for saccharification of the grain starch (Kim et al. 2000). A study reported that when germinated millets sprouts were fermented at $30^{\circ} \mathrm{C}$ with mixtures of probiotics culture consisting of Saccharomyces diasticus, Saccharomyces cerevisiae, Lactobacillus brevis and Lactobacillus fermentum for $72 \mathrm{~h}$, approx. $88.3 \%$ reduction of phytic acid content was observed (Khetrapal and Chauhan 1990). Another study by Ragon et al. (2008) concluded that phytic acid (IP6) was reduced into lower forms, such as IP5, IP4, IP3, IP2, IP1 and myoinositol by the action of microbial enzymes when rice flour was subjected to natural fermentation. In a latest study, maize flour was fermented with a consortium of lactic acid bacteria by standard method with $12 \mathrm{~h}$ intervals to check the effect of fermentation on anti-nutritional factors (Ogodo et al. 2019). The results showed that with increasing fermentation period, significant $(p<0.05)$ reductions in anti-nutrients, including tannin, polyphenol, phytate and trypsin inhibitor activity were observed in the fermented maize. Results concluded that the anti-nutritional contents were reduced more in LAB-Consortium fermentation compared to spontaneous fermentation (Ogodo et al. 2019). Research was also conducted by Etsuyankpa et al. (2015) to evaluate the effect of microbial fermentation on antinutritional composition of local cassava products. Results of the study emphasized that fermentation by microorganisms significantly decreased $(P<0.05)$ the level of cyanide, tannins, phytate, oxalate and saponins by $86,73,72,61$, and $92 \%$, respectively in the cassava products. A study by Samia et al. (2005) reported that fermentation and germination could enhance the nutritional level of cereals and legumes by altering the chemical composition and reduce the level of anti-nutritional factors.

\section{Conclusions}

This review provides essential information on the antinutritional components of cereal and legume seeds. The most common anti-nutrients present in plant materials include saponins, tannins, phytate, polyphenolic compounds, and protease inhibitors. These components interfere with the nutritional value of foods by reducing mineral absorption, protein digestibility and causing toxicity and health disorders when present in high concentrations. Nowadays, several strategies are used to overcome the effects of these food anti-nutrients, which include processing treatments such as milling, soaking, germination, autoclave and microwave treatment and fermentation. Various previous studies 
confirmed that fermentation is one of the best methods to reduce the anti-nutritional factors in foods when compared to all other methods. However, germination followed by fermentation also showed good results for reducing the level of anti-nutrients in foods. Microbial fermentation activates many endogenous enzymes like phytase, which generally degrades phytate in the food; phytate is one of the largest anti-nutrients, which is present in food crops. Previous works have established that anti-nutrients have close negative relationship with the micronutrient bioavailability because higher contents of anti-nutrients reduce availability or absorption of minerals and could lead to nutrients deficiency or malnutrition. Therefore, quality of food crops like cereals and grains can be improved by subjecting them to various processing methods, especially germination and fermentation.

\section{Abbreviations}

CVD: Cardiovascular disease; Gl: Gastrointestinal; IP: Inositol polyphosphate; LAB: Lactic acid bacteria

\section{Acknowledgements}

We thank the administrative staff of Central University of Haryana for extending all necessary facilities.

\section{Authors' contributions}

MS, REA and TD contributed to all sections and writing of the article. TD contributed to study selection and data extraction. REA contributed to analysis, interpretation and drafting of the article. MS contributed to design of the article. All authors gave approval of the final version to be submitted.

\section{Funding}

Not applicable.

\section{Availability of data and materials}

The datasets used and/or analyzed during the current study are available from the corresponding author on request.

\section{Competing interests}

The authors declare that they have no competing interests.

\section{Author details}

${ }^{1}$ Department of Nutrition Biology, Central University of Haryana, Mahendergarh, Haryana 123031, India. ${ }^{2}$ Department of Food and Human Nutritional Sciences, University of Manitoba, Winnipeg, Manitoba R3T 2N2, Canada.

Received: 31 July 2019 Accepted: 20 January 2020

Published online: 06 March 2020

\section{References}

Addisu, S., \& Assefa, A. (2016). Role of plant containing saponin on livestock production; a review. Advances in Biological Research, 10(5), 309-314.

Adeyemo, S. M., \& Onilude, A. A. (2013). Enzymatic reduction of anti-nutritional factors in fermenting soybeans by Lactobacillus plantarum isolates from fermenting cereals. Nigerian Food Journal, 31(2), 84-90.

Adeyeye, S. A., \& Akingbala, J. O. (2016). Quality, functional, and sensory properties of cookies from sweet potato-maize flour blends. Journal of Culinary Science \& Technology, 14(4), 363-376.

Ahmed, E. M. (1986). Lectin quantitation in peanut and soybean seeds. Peanut Science, 13(1), 4-7.

Al Hasan, S. M., Hassan, M., Saha, S., Islam, M., Billah, M., \& Islam, S. (2016). Dietary phytate intake inhibits the bioavailability of iron and calcium in the diets of pregnant women in rural Bangladesh: A cross-sectional study. BMC Nutrition, 2(1), 24.
Ali, H., Houghton, P. J., \& Soumyanath, A. (2006). a-Amylase inhibitory activity of some Malaysian plants used to treat diabetes; with particular reference to Phyllanthus amarus. Journal of Ethnopharmacology, 107(3), 449-455.

Amin, H. A. S., Hanna, A. G., \& Mohamed, S. S. (2011). Comparative studies of acidic and enzymatic hydrolysis for production of soyasapogenols from soybean saponin. Biocatalysis and Biotransformation, 29(6), 311-319.

Amirabdollahian, F., \& Ash, R. (2010). An estimate of phytate intake and molar ratio of phytate to zinc in the diet of the people in the United Kingdom. Public Health Nutrition, 13(9), 1380-1388.

Aoudou, Y., Ngoune Léopold, T., Dongmo Pierre Michel, J., \& Carl Moses, M. (2012). Inhibition of fungal development in maize grains under storage condition by essential oils. International Journal of Biosciences (IJB), 2(6), 41-48.

Awolu, O. O., Oluwaferanmi, P. M., Fafowora, O. I., \& Oseyemi, G. F. (2015). Optimization of the extrusion process for the production of ready-to-eat snack from rice, cassava and kersting's groundnut composite flours. LWTFood Science and Technology, 64(1), 18-24.

Awolu, O. O., Omoba, O. S., Olawoye, O., \& Dairo, M. (2017). Optimization of production and quality evaluation of maize-based snack supplemented with soybean and tiger-nut (Cyperus esculenta) flour. Food Science \& Nutrition, 5(1), 3-13.

Azeke, M. A., Egielewa, S. J., Eigbogbo, M. U., \& Ihimire, I. G. (2011). Effect of germination on the phytase activity, phytate and total phosphorus contents of rice (Oryza sativa), maize (Zea mays), millet (Panicum miliaceum), sorghum (Sorghum bicolor) and wheat (Triticum aestivum). Journal of Food Science and Technology, 48(6), 724-729.

Bajpai, S., Sharma, A., \& Gupta, M. N. (2005). Removal and recovery of antinutritional factors from soybean flour. Food Chemistry, 89(4), 497-501.

Bardocz, S., Grant, G., Ewen, S. W., Duguid, T. J., Brown, D. S., Englyst, K., \& Pusztai, A. (1995). Reversible effect of phytohaemagglutinin on the growth and metabolism of rat gastrointestinal tract. Gut, 37(3), 353-360.

Bayorbor, T. B., Dzomeku, I. K., Avornyo, V. K., \& Opoku-Agyeman, M. O. (2010). Morphological variation in Kersting's groundnut (Kerstigiella geocarpa Harms) landraces from northern Ghana. Agriculture and Biology Journal of North America, 1(3), 290-295.

Bhatia, S. C. (2016). Food biotechnology. Wpi Publishing http://www. woodheadpublishingindia.com/BookDetails.aspx?BookID=108.

Bhattarai, S., Coulman, B., \& Biligetu, B. (2016). Sainfoin (Onobrychis viciifolia Scop. ): Renewed interest as a forage legume for western Canada. Canadian Journal of Plant Science, 96(5), 748-756

Bhutkar, M. A., \& Bhise, S. B. (2012). In vitro assay of alpha amylase inhibitory activity of some indigenous plants. International Journal of Chemical Science, 10(2012), 457-462.

Birari, R. B., \& Bhutani, K. K. (2007). Pancreatic lipase inhibitors from natural sources: Unexplored potential. Drug Discovery Today, 12(19-20), 879-889.

Black, R. E., Victora, C. G., Walker, S. P., Bhutta, Z. A., Christian, P., De Onis, M., et al. (2013). Maternal and child undernutrition and overweight in low-income and middle-income countries. The Lancet, 382(9890), 427-451.

Bora, P. (2014). Anti-nutritional factors in foods and their effects. Journal of Academia and Industrial Research, 3(6), 285-290.

Bouis, H. E., Saltzman, A., \& Birol, E. (2019). Improving nutrition through biofortification. In Agriculture for improved nutrition: seizing the momentum (p. 47).

Chan, S. S., Ferguson, E. L., Bailey, K., Fahmida, U., Harper, T. B., \& Gibson, R. S. (2007). The concentrations of iron, calcium, zinc and phytate in cereals and legumes habitually consumed by infants living in East Lombok, Indonesia. Journal of Food Composition and Analysis, 20(7), 609-617.

Chandrasekara, A., \& Shahidi, F. (2011). Determination of antioxidant activity in free and hydrolyzed fractions of millet grains and characterization of their phenolic profiles by HPLC-DAD-ESI-MSn. Journal of Functional Foods, 3(3), 144-158.

Cheeke, P. R. (1971). Nutritional and physiological implications of saponins: A review. Canadian Journal of Animal Science, 51(3), 621-632.

Chen, W., Hira, T., Nakajima, S., Tomozawa, H., Tsubata, M., Yamaguchi, K., \& Hara, H. (2012). Suppressive effect on food intake of a potato extract (Potein ${ }^{\circledast}$ ) involving cholecystokinin release in rats. Bioscience, Biotechnology, and Biochemistry, 76(6), 1104-1109.

Chowdhury, S., \& Punia, D. (1997). Nutrient and antinutrient composition of pearl millet grains as affected by milling and baking. Food/Nahrung, 41(2), 105107

Coulibaly, A., Kouakou, B., \& Chen, J. (2011). Phytic acid in cereal grains: Structure, healthy or harmful ways to reduce phytic acid in cereal grains and their 
effects on nutritional quality. American Journal of Plant Nutrition and Fertilization Technology, 1(1), 1-22.

D'Mello, J. P. F. (2000). Antinutritional factors and mycotoxins. In Farm animal metabolism and nutrition (p. 383).

Dahl, S. W., Rasmussen, S. K., \& Hejgaard, J. (1996). Heterologous expression of three plant serpins with distinct inhibitory specificities. Journal of Biological Chemistry, 271(41), 25083-25088.

de Camargo, A. C., \& da Silva Lima, R. (2019). A perspective on phenolic compounds, their potential health benefits, and international regulations: The revised Brazilian normative on food supplements. Journal of Food Bioactives, 7 https://doi.org/10.3390/ijms20112644.

de Camargo, A. C., Favero, B. T., Morzelle, M. C., Franchin, M., Alvarez-Parrilla, E., de la Rosa, L. A., et al. (2019). Is chickpea a potential substitute for soybean? Phenolic bioactives and potential health benefits. International Journal of Molecular Sciences, 20(11), 2644.

De Vasconcelos, M. C. B. M., Bennett, R., Castro, C. A. B. B., Cardoso, P., Saavedra, M. J., \& Rosa, E. A. (2013). Study of composition, stabilization and processing of wheat germ and maize industrial by-products. Industrial Crops and Products, 42, 292-298 https://doi.org/10.1016/j.indcrop.2012.06.007.

Doss, A., Pugalenthi, M., Vadivel, V. G., Subhashini, G., \& Subash, A. R. (2011). Effects of processing technique on the nutritional composition and antinutrients content of under-utilized food legume Canavalia ensiformis L. DC. International Food Research Journal, 18(3), 965-970 http://www.ifrj.upm. edu.my/18\%20(03)\%202011/(15)IFRJ-2010-260.pdf.

Ebert, A. (2014). Potential of underutilized traditional vegetables and legume crops to contribute to food and nutritional security, income and more sustainable production systems. Sustainability, 6(1), 319-335.

Edema, M. O., Sanni, L. O., \& Sanni, A. I. (2005). Evaluation of maize-soybean flour blends for sour maize bread production in Nigeria. African Journal of Biotechnology, 4(9), 911-918 https://www.ajol.info/index.php/ajb/article/view/ 71122/60095.

Ekpa, O., Palacios-Rojas, N., Kruseman, G., Fogliano, V., \& Linnemann, A. R. (2018). Sub-Saharan African maize-based foods: Technological perspectives to increase the food and nutrition security impacts of maize breeding programmes. Global Food Security, 17, 48-56.

Embaby, H. E. S. (2010). Effect of heat treatments on certain antinutrients and in vitro protein digestibility of peanut and sesame seeds. Food Science and Technology Research, 17(1), 31-38.

Ercan, P., \& El, S. N. (2016). Inhibitory effects of chickpea and Tribulus terrestris on lipase, a-amylase and a-glucosidase. Food Chemistry, 205, 163-169.

Ertaş, N., \& Türker, S. (2014). Bulgur processes increase nutrition value: Possible role in in-vitro protein digestability, phytic acid, trypsin inhibitor activity and mineral bioavailability. Journal of Food Science and Technology, 51(7), 1401-1405.

Ertop, M. H., \& Bektaş, M. (2018). Enhancement of bioavailable micronutrients and reduction of antinutrients in foods with some processes. Food and Health, 4(3), 159-165.

Etsuyankpa, M. B., Gimba, C. E., Agbaji, E. B., Omoniyi, l., Ndamitso, M. M., \& Mathew, J. T. (2015). Assessment of the effects of microbial fermentation on selected anti-nutrients in the products of four local cassava varieties from Niger state, Nigeria. American Journal of Food Science and Technology, 3(3), 89-96.

FAO. (2002). Groundnut: Post-harvest operations. Rome: FAO.

FAO. (2009). FAOSTAT. Food and Agriculture Organisation of the United Nations. FAOSTAT. Retrieved from http://faostat.fao.org/site/339/default.aspx.

FAO (2018a) http://www.fao.org/gsfaonline/docs/CXs_192e.pdf

FAO. (2018b). Anti-nutritional factors within feed ingredients. Rome: Aquaculture Feed and Fertilizer Resources Information System, Food and Agriculture Organizations of the United Nations http://www.fao.org/fishery/affris/feedresources-database.anti-nutritional-factors-within-feed ingredients/en/. Accessed 28 Nov 2018

FAOSTAT. (2017). Rice, production/crops/world for 2016. Rome: Food and Agricultural Organization of the United Nations, Statistics Division (FAOSTAT).

Faostat, F. (2016). FAOSTAT statistical database. Rome: FAO (Food and Agriculture Organization of the United Nations).

Fenwick, G. R., Price, K. R., Tsukamoto, C., \& Okubo, K. (1991). Saponins. In F. J. P. D'Mello, C. M. Duffus, \& J. H. Duffus (Eds.), Toxic substances in crop plants (pp. 285-327).

Fleck, J. D., Betti, A. H., Da Silva, F. P., Troian, E. A., Olivaro, C., Ferreira, F., \& Verza, S. G. (2019). Saponins from Quillaja saponaria and Quillaja brasiliensis: Particular chemical characteristics and biological activities. Molecules, 24(1), 171.
Food and Agricultural Organization of the United Nations. (2004). Rice is life. Rome. http://www.fao.org/3/a-y5682e.pdf

Francis, G., Kerem, Z., Makkar, H. P., \& Becker, K. (2002). The biological action of saponins in animal systems: A review. British Journal of Nutrition, 88(6), 587-605.

Frutos, P., Hervas, G., Giráldez, F. J., \& Mantecón, A. R. (2004). Tannins and ruminant nutrition. Spanish Journal of Agricultural Research, 2(2), 191-202.

Galati, A., Oguntoyinbo, F. A., Moschetti, G., Crescimanno, M., \& Settanni, L. (2014). The cereal market and the role of fermentation in cereal-based food production in Africa. Food Reviews International, 30(4), 317-337.

García-Estepa, R. M., Guerra-Hernández, E., \& García-Villanova, B. (1999). Phytic acid content in milled cereal products and breads. Food Research International, 32(3), 217-221.

Gemede, H. F., \& Ratta, N. (2014). Antinutritional factors in plant foods: Potential health benefits and adverse effects. International Journal of Nutrition and Food Sciences, 3(4), 284-289.

Gibson, L., \& Benson, G. (2005). Origin, history, and uses of soybean (Glycine max). lowa State University, Department of Agronomy. https://scholar.google.com/ scholar_lookup?hl=en-IN\&publication_year=2005\&author=L.+ Gibson\&author=G.+Benson\&title=Origin\%2C+history\%2C+and+uses+of+ soybean+\%28Glycine+max\%29

Gibson, R. S., Bailey, K. B., Gibbs, M., \& Ferguson, E. L. (2010). A review of phytate, iron, zinc, and calcium concentrations in plant-based complementary foods used in low-income countries and implications for bioavailability. Food and Nutrition Bulletin, 31(2_suppl2), S134-S146.

Gomes, M. T. R., Oliva, M. L., Lopes, M. T. P., \& Salas, C. E. (2011). Plant proteinases and inhibitors: An overview of biological function and pharmacological activity. Current Protein and Peptide Science, 12(5), 417-436.

Gopalan, C. R. B. V., Sastri, B. R., \& Balasubramanian, S. C. (1989). Nutritive value of Indian foods. National Institute of Nutrition, Indian Council of Medical Research. https://www.icmr.nic.in/content/nutritive-value-indian-foods-nvif-cgopalan-b-v-rama-sastri-sc-balasubramanian-revised

Grases, F., Prieto, R. M., \& Costa-Bauza, A. (2017). Dietary phytate and interactions with mineral nutrients. In Clinical aspects of natural and added phosphorus in foods (pp. 175-183). New York: Springer.

Greiner, R., \& Konietzny, U. (2006). Phytase for food application. Food Technology \& Biotechnology, 44(2).

Gupta, R. K., Gangoliya, S. S., \& Singh, N. K. (2015). Reduction of phytic acid and enhancement of bioavailable micronutrients in food grains. Journal of Food Science and Technology, 52(2), 676-684.

Gwirtz, J. A., \& Garcia-Casal, M. N. (2014). Processing maize flour and corn meal food products. Annals of the New York Academy of Sciences, 1312(1), 66.

Habib, H., \& Fazili, K. M. (2007). Plant protease inhibitors: A defense strategy in plants. Biotechnology and Molecular Biology Reviews, 2(3), 68-85.

Hamid, R., Masood, A., Wani, I. H., \& Rafiq, S. (2013). Lectins: Proteins with diverse applications. Journal of Applied Pharmaceutical Science, 3(4), S93-S103.

Handa, V., Kumar, V., Panghal, A., Suri, S., \& Kaur, J. (2017). Effect of soaking and germination on physicochemical and functional attributes of horsegram flour. Journal of Food Science and Technology, 54(13), 4229-4239.

Haq, S. K., Atif, S. M., \& Khan, R. H. (2005). Biochemical characterization, stability studies and $\mathrm{N}$-terminal sequence of a bi-functional inhibitor from Phaseolus aureus Roxb. (Mung bean). Biochimie, 87(12), 1127-1136.

Herzig, K. H., Bardocz, S., Grant, G., Nustede, R., Fölsch, U. R., \& Pusztai, A. (1997). Red kidney bean lectin is a potent cholecystokinin releasing stimulus in the rat inducing pancreatic growth. Gut, 41(3), 333-338.

Hossain, M. S., Singh, A. K., \& Fasih-uz-Zaman. (2009). Cooking and eating characteristics of some newly identified inter sub-specific (indica/japonica) rice hybrids. ScienceAsia, 35(4), 320-325.

Ihekoronye, A. I., \& Ngoddy, P. O. (1985). Integrated food science and technology for the tropics. London: Macmillan https://www.cabdirect.org/cabdirect/ abstract/19860409222.

Jansman, A. J. M., Hill, G. D., Huisman, J., \& van der Poel, A. F. (1998). Recent advances of research in antinutritional factors in legume seeds (p. 76). Wageningen: Wageningen Pers.

Jaybhaye, R. V., \& Srivastav, P. P. (2015). Development of barnyard millet ready-toeat snack food: Part II. Food Science Research Journal, 6(2), 285-291.

Jenkins, K. J., \& Atwal, A. S. (1994). Effects of dietary saponins on fecal bile acids and neutral sterols, and availability of vitamins $A$ and $E$ in the chick. The Journal of Nutritional Biochemistry, 5(3), 134-137.

Joye, I. (2019). Protein digestibility of cereal products. Foods, 8(6), 199.

Kataria, A., Chauhan, B. M., \& Punia, D. (1989). Antinutrients in amphidiploids (black gram $\times$ mung bean): Varietal differences and effect of domestic processing and cooking. Plant Foods for Human Nutrition, 39(3), 257-266. 
Katina, K., Arendt, E., Liukkonen, K. H., Autio, K., Flander, L., \& Poutanen, K. (2005). Potential of sourdough for healthier cereal products. Trends in Food Science \& Technology, 16(1-3), 104-112.

Kaukovirta-Norja, A., Wilhelmson, A., \& Poutanen, K. (2004). Germination: A means to improve the functionality of oat.

Kaur, K. D., Jha, A., Sabikhi, L., \& Singh, A. K. (2014). Significance of coarse cereals in health and nutrition: A review. Journal of Food Science and Technology, 51(8), 1429-1441.

Kaushal, P., Kumar, V., \& Sharma, H. K. (2012). Comparative study of physicochemical, functional, antinutritional and pasting properties of taro (Colocasia esculenta), rice (Oryza sativa) flour, pigeonpea (Cajanus cajan) flour and their blends. LWT-Food Science and Technology, 48(1), 59-68.

Kaushik, G., Singhal, P., \& Chaturvedi, S. (2018). Food processing for increasing consumption: The case of legumes. In Food processing for increased quality and consumption (pp. 1-28). Academic. https://www.scribd.com/book/3786 77055/Food-Processing-for-Increased-Quality-and-Consumption

Kavitha, S., \& Parimalavalli, R. (2014). Effect of processing methods on proximate composition of cereal and legume flours. Journal of Human Nutrition and Food Science, 2(4), 1051.

Kennedy, G., \& Burlingame, B. (2003). Analysis of food composition data on rice from a plant genetic resources perspective. Food Chemistry, 80(4), 589-596.

Khetrapal, N., \& Chauhan, B. M. (1990). Fermentation of pearl millet flour with yeasts and lactobacilli, in vitro digestibility and utilization of fermented flour for weaning mixtures. Plant Foods for Human Nutrition, 40, 167-173.

Kies, A. K., De Jonge, L. H., Kemme, P. A., \& Jongbloed, A. W. (2006). Interaction between protein, phytate, and microbial phytase. In vitro studies. Journal of Agricultural and Food Chemistry, 54(5), 1753-1758.

Kim, H. Y., Min, J. H., Lee, J. H., \& Ji, G. E. (2000). Growth of lactic acid bacteria and bifidobacteria in natural media using vegetables, seaweeds, grains and potatos. Food Science and Biotechnology, 9(5), 322-324.

Kiranmayi, P. (2014). Is bio active compounds inplantsacts as anti nutritonal factors. International Journal of Current Pharmaceutical Research, 6(2), 36-38.

Kregiel, D., Berlowska, J., Witonska, l., Antolak, H., Proestos, C., Babic, M., et al. (2017). Saponin-based, biological-active surfactants from plants. In Application and characterization of surfactants (pp. 183-205).

Kruger, J., Oelofse, A., \& Taylor, J. R. (2014). Effects of aqueous soaking on the phytate and mineral contents and phytate: Mineral ratios of wholegrain normal sorghum and maize and low phytate sorghum. International Journal of Food Sciences and Nutrition, 65(5), 539-546.

Krupa, U. (2008). Main nutritional and antinutritional compounds of bean seeds-a review. Polish Journal of Food and Nutrition Sciences, 58(2), 149-155.

Kumar, R. (1992). Anti-nutritional factors, the potential risks of toxicity and methods to alleviate them. In Legume trees and other fodder trees as protein source for livestock. FAO animal production and health paper, 102 (pp. 145160).

Kumar, S., Narwal, S., Kumar, V., \& Prakash, O. (2011). a-Glucosidase inhibitors from plants: A natural approach to treat diabetes. Pharmacognosy Reviews, 5(9), 19.

Kumari, D., Chandrasekara, A., \& Shahidi, F. (2019). Bioaccessibility and antioxidant activities of finger millet food phenolics. Journal of Food Bioactives, 6, 100109 https://doi.org/10.31665/JFB.2019.6187.

Kumari, S. (2018). The effect of soaking almonds and hazelnuts on Phytate and mineral concentrations. Doctoral dissertation, University of Otago. https:// ourarchive.otago.ac.nz/bitstream/handle/10523/7938/KumariShivani201 7MDiet.pdf? sequence=1\&isAllowed=y

Kwun, I. S., \& Kwon, C. S. (2000). Dietary molar ratios of phytate: Zinc and millimolar ratios of phytatex calcium: Zinc in south Koreans. Biological Trace Element Research, 75(1-3), 29.

Lajolo, F. M., \& Genovese, M. I. (2002). Nutritional significance of lectins and enzyme inhibitors from legumes. Journal of Agricultural and Food Chemistry, 50(22), 6592-6598.

Lampart-Szczapa, E., Siger, A., Trojanowska, K., Nogala-Kalucka, M., Malecka, M., \& Pacholek, B. (2003). Chemical composition and antibacterial activities of lupin seeds extracts. Food/Nahrung, 47(5), 286-290.

Larsson, M., \& Sandberg, A. S. (1992). Phytate reduction in oats during malting. Journal of Food Science, 57(4), 994-997.

Laxmi, G., Chaturvedi, N., \& Richa, S. (2015). The impact of malting on nutritional composition of foxtail millet, wheat and chickpea. Journal of Nutrition and Food Sciences, 5(5), 1-3.

Lee, J. H., Moon, S. J., \& Huh, K. B. (1993). Influence of phytate and low dietary calcium on calcium, phosphate and zinc metabolism by growing rats. Journal of Nutrition and Health, 26(2), 145-155.
Lee, S. S., Mohd Esa, N., \& Loh, S. P. (2015). In vitro inhibitory activity of selected legumes against pancreatic lipase. Journal of Food Biochemistry, 39(4), 485490.

Li, L., \& Tsao, R. (2019). UF-LC-DAD-MSn for discovering enzyme inhibitors for nutraceuticals and functional foods. Journal of Food Bioactives, 7, 27-35 https://doi.org/10.31665/JFB.2019.7195.

Liener, I. E. (2003). Phytohemagglutinins: Their nutritional significance. Journal of Agricultural and Food Chemistry, 22, 17.

Liu, K. (1997). Chemistry and nutritional value of soybean components. In Soybeans (pp. 25-113). Boston: Springer.

Lolas, G. M. (1976). The phytic acid-total phosphorus relationship in barley, oats, soybeans, and wheat. Cereal Chemistry, 53, 867-871.

Lönnerdal, B. (2002). Phytic acid-trace element (Zn, Cu, Mn) interactions. International Journal of Food Science \& Technology, 37(7), 749-758.

Lott, J. N., Ockenden, I., Raboy, V., \& Batten, G. D. (2000). Phytic acid and phosphorus in crop seeds and fruits: a global estimate. Seed Science Research, 10(1), 11-33.

Mahgoub, S. E., \& Elhag, S. A. (1998). Effect of milling, soaking, malting, heattreatment and fermentation on phytate level of four Sudanese sorghum cultivars. Food Chemistry, 61(1-2), 77-80.

Makokha, A. O., Oniang'o, R. K., Njoroge, S. M., \& Kamar, O. K. (2002). Effect of traditional fermentation and malting on phytic acid and mineral availability from sorghum (Sorghum bicolor) and finger millet (Eleusine coracana) grain varieties grown in Kenya. Food and Nutrition Bulletin, 23(3_suppl1), 241-245.

Malik, S. (2015). Pearl Millet-Nutritional value and medicinal uses! International Journal of Advance Research and Innovative Ideas in Education, 1(3), 414-418.

Manisseri, C., \& Gudipati, M. (2012). Prebiotic activity of purified xylobiose obtained from ragi (Eleusine coracana, Indaf-15) bran. Indian Journal of Microbiology, 52(2), 251-257.

Maphosa, Y., \& Jideani, V. A. (2017). The role of legumes in human nutrition. M. Chavarri. Functional Food Improve Health through Adequate Food, 103-109 https://www.intechopen.com/books/functional-food-improve-healththrough-adequate-food.

Margier, M., Georgé, S., Hafnaoui, N., Remond, D., Nowicki, M., Du Chaffaut, L., et al. (2018). Nutritional composition and bioactive content of legumes: Characterization of pulses frequently consumed in France and effect of the cooking method. Nutrients, 10(11), 1668.

Mohapatra, D., Patel, A. S., Kar, A., Deshpande, S. S., \& Tripathi, M. K. (2019). Effect of different processing conditions on proximate composition, anti-oxidants, anti-nutrients and amino acid profile of grain sorghum. Food Chemistry, 271, 129-135.

Morzelle, M. C., Salgado, J. M., Massarioli, A. P., Bachiega, P., de Oliveira Rios, A., Alencar, S. M., et al. (2019). Potential benefits of phenolics from pomegranate pulp and peel in Alzheimer's disease: Antioxidant activity and inhibition of acetylcholinesterase. Journal of Food Bioactives, 5, 136-141.

Moses, T., Papadopoulou, K. K., \& Osbourn, A. (2014). Metabolic and functional diversity of saponins, biosynthetic intermediates and semi-synthetic derivatives. Critical Reviews in Biochemistry and Molecular Biology, 49(6), 439462.

Muramoto, K. (2017). Lectins as bioactive proteins in foods and feeds. Food Science and Technology Research, 23(4), 487-494.

Mustafa, K. D., \& Adem, E. (2014). Comparison of autoclave, microwave, IR and UV-stabilization of whole wheat flour branny fractions upon the nutritional properties of whole wheat bread. Journal of Food Science and Technology, 51(1), 59-66.

Nadeem, M., Anjum, F. M., Amir, R. M., Khan, M. R., Hussain, S., \& Javed, M. S. (2010). An overview of anti-nutritional factors in cereal grains with special reference to wheat-A review. Pakistan Journal of Food Sciences, 20(1-4), 5461.

Nduti, N., McMillan, A., Seney, S., Sumarah, M., Njeru, P., Mwaniki, M., \& Reid, G. (2016). Investigating probiotic yoghurt to reduce an aflatoxin B1 biomarker among school children in eastern Kenya: Preliminary study. International Dairy Journal, 63, 124-129.

Nikmaram, N., Leong, S. Y., Koubaa, M., Zhu, Z., Barba, F. J., Greiner, R., et al. (2017). Effect of extrusion on the anti-nutritional factors of food products: An overview. Food Control, 79, 62-73.

Nkhata, S. G., Ayua, E., Kamau, E. H., \& Shingiro, J. B. (2018). Fermentation and germination improve nutritional value of cereals and legumes through activation of endogenous enzymes. Food Science \& Nutrition, 6(8), 2446-2458.

Nørgaard, J. V., Malla, N., Dionisio, G., Madsen, C. K., Pettersson, D., Lærke, H. N., et al. (2019). Exogenous xylanase or protease for pigs fed barley cultivars with 
high or low enzyme inhibitors. Animal Feed Science and Technology, 248, 5966.

Oboh, G., Ademiluyi, A. O., \& Akindahunsi, A. A. (2010). The effect of roasting on the nutritional and antioxidant properties of yellow and white maize varieties. International Journal of Food Science \& Technology, 45(6), 1236-1242.

Ogbonna, A. C., Abuajah, C. I., Ide, E. O., \& Udofia, U. S. (2012). Effect of malting conditions on the nutritional and anti-nutritional factors of sorghum grist. Annals of the University Dunarea de Jos of Galati Fascicle VI--Food Technology, 36(2), 64-72 https://doaj.org/article/b14b46c570b74603b13c5beb9421e0b5.

Oghbaei, M., \& Prakash, J. (2016). Effect of primary processing of cereals and legumes on its nutritional quality: A comprehensive review. Cogent Food \& Agriculture, 2(1), 1136015.

Ogodo, A. C., Agwaranze, D. I., Aliba, N. V., Kalu, A. C., \& Nwaneri, C. B. (2019). Fermentation by lactic acid Bacteria consortium and its effect on antinutritional factors in maize flour. Journal of Biological Sciences, 19, 17-23 https://doi.org/10.3923/jbs.2019.17.23.

Okaka, J. C. (1997). Cereals and legumes: Storage and processing technology. In Data and micro systems publishers Ogui-Enugu (pp. 116-131).

Onwuka, G. I. (2006). Soaking, boiling and antinutritional factors in pigeon peas (Cajanus cajan) and cowpeas (Vigna unguiculata). Journal of Food Processing and Preservation, 30(5), 616-630.

Onyango, C. A., Ochanda, S. O., Mwasaru, M. A., Ochieng, J. K., Mathooko, F. M., \& Kinyuru, J. N. (2013). Effects of malting and fermentation on anti-nutrient reduction and protein digestibility of red sorghum, white sorghum and pearl millet. Journal of Food Research, 2(1), 41.

Otlewski, J., Jelen, F., Zakrzewska, M., \& Oleksy, A. (2005). The many faces of protease-protein inhibitor interaction. The EMBO Journal, 24(7), 1303-1310.

Paramita, B., Singhal, R. S., \& Kulkarni, P. R. (2002). Review Basmati rice: A review. International Journal of Food Science and Technology, 37, 1-12.

Pariza, W. M. (1996). Toxic substances. Food chemistry (3rd ed. pp. 825-841). New York: Marcel Dekker.

Patterson, C. A., Curran, J., \& Der, T. (2017). Effect of processing on antinutrient compounds in pulses. Cereal Chemistry, 94(1), 2-10.

Polak, R., Phillips, E. M., \& Campbell, A. (2015). Legumes: Health benefits and culinary approaches to increase intake. Clinical Diabetes, 33(4), 198-205.

Prasad, A. S., Miale, A., Farid, Z., Sandstead, H. H., Schulert, A. R., \& Darby, W. J. (1963). Biochemical studies on dwarfism, hypogonadism, and anemia. Archives of Internal Medicine, 111(4), 407-428.

Raboy, V. (2000). Low-phytic-acid grains. Food and Nutrition Bulletin, 21(4), 423-427.

Raes, K., Knockaert, D., Struijs, K., \& Van Camp, J. (2014). Role of processing on bioaccessibility of minerals: Influence of localization of minerals and antinutritional factors in the plant. Trends in Food Science \& Technology, 37(1), 32-41.

Ragon, M., Aumelas, A., Chemardin, P., Galvez, S., Moulin, G., \& Boze, H. (2008). Complete hydrolysis of myo-inositol hexakisphosphate by a novel phytase from Debaryomyces castellii CBS 2923. Applied Microbiology and Biotechnology, 78(1), 47-53.

Ranum, P., Peña-Rosas, J. P., \& Garcia-Casal, M. N. (2014). Global maize production, utilization, and consumption. Annals of the New York Academy of Sciences, 1312(1), 105-112.

Ray, R. C., \& Didier, M. (Eds.). (2014). Microorganisms and fermentation of traditional foods. CRC Press https://www.crcpress.com/Microorganisms-andFermentation-of-Traditional-Foods/Ray-Didier/p/book/9781482223088.

Ray, M., Ghosh, K., Singh, S., \& Mondal, K. C. (2016). Folk to functional: an explorative overview of rice-based fermented foods and beverages in India. Journal of Ethnic Foods, 3(1), 5-18.

Reddy, N. R., \& Pierson, M. D. (1994). Reduction in antinutritional and toxic components in plant foods by fermentation. Food Research International, 27(3), 281-290.

Rehman, Z. U., \& Shah, W. H. (2005). Thermal heat processing effects on antinutrients, protein and starch digestibility of food legumes. Food Chemistry, 91, 327-331.

Ribeiro, J. A. D. N. C., Serquiz, A. C., Silva, P. F. D. S., Barbosa, P. B. B. M., Sampaio, T. B. M., Junior, A., et al. (2015). Trypsin inhibitor from Tamarindus indica L. seeds reduces weight gain and food consumption and increases plasmatic cholecystokinin levels. Clinics, 70(2), 136-143.

Rose, D. J., Inglett, G. E., \& Liu, S. X. (2010). Utilisation of corn (Zea mays) bran and corn fiber in the production of food components. Journal of the Science of Food and Agriculture, 90(6), 915-924.

Salas, C. E., Dittz, D., \& Torres, M. J. (2018). Plant proteolytic enzymes: Their role as natural pharmacophores. In Biotechnological applications of plant proteolytic enzymes (pp. 107-127). Cham: Springer.
Samia, M., AbdelRahaman, B., \& Elfadil, E. (2005). Effect of malt pretreatment followed by fermentation on antinutritional factors and $\mathrm{HCl}$ extractability of minerals of pearl millet cultivars. Journal of Food Technology, 3(4), 529-534.

Sánchez-Chino, X., Jiménez-Martínez, C., Dávila-Ortiz, G., Álvarez-González, I., \& Madrigal-Bujaidar, E. (2015). Nutrient and nonnutrient components of legumes, and its chemopreventive activity: a review. Nutrition and Cancer, 67(3), 401-410.

Sarita, E. S., \& Singh, E. (2016). Potential of millets: nutrients composition and health benefits. Journal of Scientific and Innovative Research, 5(2), 46-50.

Savage, G. P., \& Mårtensson, L. (2010). Comparison of the estimates of the oxalate content of taro leaves and corms and a selection of Indian vegetables following hot water, hot acid and in vitro extraction methods. Journal of Food Composition and Analysis, 23(1), 113-117.

Schlemmer, U., Frølich, W., Prieto, R. M., \& Grases, F. (2009). Phytate in foods and significance for humans: food sources, intake, processing, bioavailability, protective role and analysis. Molecular Nutrition \& Food Research, 53(S2), S330-S375.

Seigler, D.S. (2005). Integrative biology 363. Plants and Their Uses, 217, 333-7577.

Serquiz, A. C., Machado, R. J., Serquiz, R. P., Lima, V. C., de Carvalho, F. M. C., Carneiro, M. A., et al. (2016). Supplementation with a new trypsin inhibitor from peanut is associated with reduced fasting glucose, weight control, and increased plasma CCK secretion in an animal model. Journal of Enzyme Inhibition and Medicinal Chemistry, 31(6), 1261-1269.

Serrano, J., Puupponen-Pimiä, R., Dauer, A., Aura, A. M., \& Saura-Calixto, F. (2009). Tannins: current knowledge of food sources, intake, bioavailability and biological effects. Molecular Nutrition \& Food Research, 53(S2), S310-S329.

Shah, W. H. (2001). Tannin contents and protein digestibility of black grams (Vigna mungo) after soaking and cooking. Plant Foods for Human Nutrition, 56(3), 265-273.

Shi, Z., Yao, Y., Zhu, Y., \& Ren, G. (2016). Nutritional composition and antioxidant activity of twenty mung bean cultivars in China. The Crop Journal, 4(5), 398406.

Shimelis, E. A., \& Rakshit, S. K. (2007). Effect of processing on antinutrients and in vitro protein digestibility of kidney bean (Phaseolus vulgaris L.) varieties grown in East Africa. Food Chemistry, 103(1), 161-172.

Shivaraj, B., \& Pattabiraman, T. N. (1981). Natural plant enzyme inhibitors. Characterization of an unusual a-amylase/trypsin inhibitor from ragi (Eleusine coracana Geartn.). Biochemical Journal, 193(1), 29-36.

Silva, M. B. R., Falcão, H. G., Kurozawa, L. E., Prudencio, S. H., de Camargo, A. C., Shahidi, F., \& Ida, E. I. (2019). Ultrasound-and hemicellulase-assisted extraction increase $\beta$-glucosidase activity, the content of isoflavone aglycones and antioxidant potential of soymilk. Journal of Food Bioactives, 6, 140-147 https://doi.org/10.31665/JFB.2019.6191.

Simwaka, J. E., Chamba, M. V. M., Huiming, Z., Masamba, K. G., \& Luo, Y. (2017). Effect of fermentation on physicochemical and antinutritional factors of complementary foods from millet, sorghum, pumpkin and amaranth seed flours. International Food Research Journal, 24(5), 1869-1879 http://www.ifrj. upm.edu.my/24\%20(05)\%202017/(5).pdf.

Singh, A., Gupta, S., Kaur, R., \& Gupta, H. R. (2017). Process optimization for antinutrient minimization of millets. Asian Journal of Dairy and Food Research, 36(4), 1-5.

Singh, N., Kaur, L., Sodhi, N. S., \& Sekhon, K. S. (2005). Physicochemical, cooking and textural properties of milled rice from different Indian rice cultivars. Food Chemistry, 89(2), 253-259.

Singh, S., Gupta, A. K., \& Kaur, N. (2012). Influence of drought and sowing time on protein composition, antinutrients, and mineral contents of wheat. The Scientific World Journal, 2012 https://doi.org/10.1100/2012/485751.

Sinha, K., \& Khare, V. (2017). Review on: Antinutritional factors in vegetable crops.

Smeriglio, A., Barreca, D., Bellocco, E., \& Trombetta, D. (2017). Proanthocyanidins and hydrolysable tannins: occurrence, dietary intake and pharmacological effects. British Journal of Pharmacology, 174(11), 1244-1262.

Sokrab, A. M., Mohamed Ahmed, I. A., \& Babiker, E. E. (2011). Effect of genotype on chemical composition, total energy, antinutrients, and total and extractable minerals of corn. International Journal of Agricultural Research and Reviews, 1, 38-43.

Stalker, H. T. (1997). Peanut (Arachis hypogaea L.). Field Crops Research, 53(1-3), 205-217.

Suhem, K., Matan, N., Matan, N., Danworaphong, S., \& Aewsiri, T. (2015). Improvement of the antifungal activity of Litsea cubeba vapor by using a helium-neon ( $\mathrm{He}-\mathrm{Ne}$ ) laser against Aspergillus flavus on brown rice snack bars. International Journal of Food Microbiology, 215, 157-160. 
Suma, P. F., \& Urooj, A. (2014). Nutrients, antinutrients \& bioaccessible mineral content (invitro) of pearl millet as influenced by milling. Journal of Food Science and Technology, 51(4), 756-761.

Tajoddin, M., Manohar, S., \& Lalitha, J. (2014). Effect of soaking and germination on polyphenol content and polyphenol oxidase activity of mung bean (Phaseolus aureus L.) cultivars differing in seed color. International Journal of Food Properties, 17(4), 782-790

Temba, M. C., Njobeh, P. B., Adebo, O. A., Olugbile, A. O., \& Kayitesi, E. (2016). The role of compositing cereals with legumes to alleviate protein energy malnutrition in Africa. International Journal of Food Science \& Technology, 51(3), 543-554

Tenaillon, M. I., \& Charcosset, A. (2011). A European perspective on maize history. Comptes Rendus Biologies, 334(3), 221-228.

Tian, S., Sun, Y., Chen, Z., Yang, Y., \& Wang, Y. (2019). Functional properties of polyphenols in grains and effects of physicochemical processing on polyphenols. Journal of Food Quality, 2019 https://doi.org/10.1155/2019/2793973.

Timotheo, C. A., \& Lauer, C. M. (2018). Toxicity of vegetable tannin extract from Acacia mearnsii in Saccharomyces cerevisiae. International Journal of Environmental Science and Technology, 15(3), 659-664.

Torres, J., Rutherfurd, S. M., Muñoz, L. S., Peters, M., \& Montoya, C. A. (2016). The impact of heating and soaking on the in vitro enzymatic hydrolysis of protein varies in different species of tropical legumes. Food Chemistry, 194, 377-382.

Udensi, E. A., Arisa, N. U., \& Maduka, M. (2008). Effects of processing methods on the levels of some antinutritional factors in Mucuna flagellipes. Nigerian Food Journal, 26(2) https://doi.org/10.4314/nifoj.v26i2.47437.

Vadivel, V., \& Biesalski, H. K. (2012). Effect of certain indigenous processing methods on the bioactive compounds of ten different wild type legume grains. Journal of Food Science and Technology, 49(6), 673-684.

Vadivel, V., Pugalenthi, M., \& Megha, S. (2008). Biological evaluation of protein quality of raw and processed seeds of gila bean (Entada scandens Benth.). Tropical and Subtropical Agroecosystems, 8(2), 125-133.

Vagadia, B. H., Vanga, S. K., \& Raghavan, V. (2017). Inactivation methods of soybean trypsin inhibitor-A review. Trends in Food Science \& Technology, 64, 115-125.

Van Der Ven, C., Matser, A. M., \& Van den Berg, R. W. (2005). Inactivation of soybean trypsin inhibitors and lipoxygenase by high-pressure processing. Journal of Agricultural and Food Chemistry, 53(4), 1087-1092.

Vashishth, A., Ram, S., \& Beniwal, V. (2017). Cereal phytases and their importance in improvement of micronutrients bioavailability. 3 Biotech, 7(1), 42.

Vaz Patto, M. C., Amarowicz, R., Aryee, A. N., Boye, J. I., Chung, H. J., MartínCabrejas, M. A., \& Domoney, C. (2015). Achievements and challenges in improving the nutritional quality of food legumes. Critical Reviews in Plant Sciences, 34(1-3), 105-143.

Vidal-Valverde, C., Frias, J., Estrella, I., Gorospe, M. J., Ruiz, R., \& Bacon, J. (1994). Effect of processing on some antinutritional factors of lentils. Journal of Agricultural and Food Chemistry, 42(10), 2291-2295.

Vincken, J. P., Heng, L., de Groot, A., \& Gruppen, H. (2007). Saponins, classification and occurrence in the plant kingdom. Phytochemistry, 68(3), 275-297.

Wang, J., Vanga, S. K., Saxena, R., Orsat, V., \& Raghavan, V. (2018). Effect of climate change on the yield of cereal crops: A review. Climate, 6(2), 41.

Wani, A. A., Singh, P., Shah, M. A., Schweiggert-Weisz, U., Gul, K., \& Wani, I. A. (2012). Rice starch diversity: Effects on structural, morphological, thermal, and physicochemical properties-A review. Comprehensive Reviews in Food Science and Food Safety, 11(5), 417-436.

Williams, M. C. (1978). Toxicity of saponins in alfombrilla (Drymaria arenarioides). Rangeland Ecology \& Management/Journal of Range Management Archives, 31 182-184.

Wilson, R. P., Robinson, E. H., \& Poe, W. E. (1981). Apparent and true availability of amino acids from common feed ingredients for channel catfish. The Journal of Nutrition, 111(5), 923-929.

Yasmin, A., Zeb, A., Khalil, A. W., Paracha, G. M. U. D., \& Khattak, A. B. (2008). Effect of processing on anti-nutritional factors of red kidney bean (Phaseolus vulgaris) grains. Food and Bioprocess Technology, 1(4), 415-419.

Yoshiara, L. Y., Mandarino, J. M. G., Carrão-Panizzi, M. C., Madeira, T. B., da Silva, J. B., de Camargo, A. C., et al. (2018). Germination changes the isoflavone profile and increases the antioxidant potential of soybean. Journal of Food Bioactives, 3, 144-150.

Zhang, G., Xu, Z., Gao, Y., Huang, X., Zou, Y., \& Yang, T. (2015). Effects of germination on the nutritional properties, phenolic profiles, and antioxidant activities of buckwheat. Journal of Food Science, 80(5), H1111-H1119.
Zujko, M. E., Terlikowska, K. M., Zujko, K., Paruk, A., \& Witkowska, A. M. (2016). Sprouts as potential sources of dietary antioxidants in human nutrition. Progress in Health Sciences, 6(2), 77-83.

\section{Publisher's Note}

Springer Nature remains neutral with regard to jurisdictional claims in published maps and institutional affiliations.
Ready to submit your research? Choose BMC and benefit from:

- fast, convenient online submission

- thorough peer review by experienced researchers in your field

- rapid publication on acceptance

- support for research data, including large and complex data types

- gold Open Access which fosters wider collaboration and increased citations

- maximum visibility for your research: over $100 \mathrm{M}$ website views per year

At BMC, research is always in progress.

Learn more biomedcentral.com/submissions 